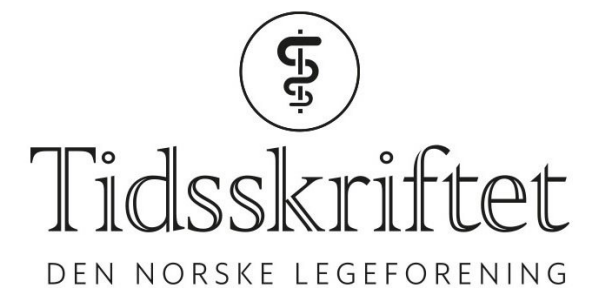

DEN NORSKE LEGEFORENING

\title{
Er cannabis blitt farligere?
}

KOMMENTAR

ANDREAS WAHL BLOMKVIST

E-post:andreas.wahl@gmail.com

Andreas Wahl Blomkvist er lege i rus- og avhengighetsmedisin.

\section{DAGFINN HESSEN PAUST}

Ingen av forfatterne har oppgitt noen interessekonflikter.

Jørgen G. Bramness og Anne Line Bretteville-Jensen spør om cannabis er farligere enn tidligere antatt, da en ny metaanalyse anslår forekomsten av avhengighet blant brukere til $13 \%$, kontra $10 \%$ i tidligere forskning (1). Usikkerheten knyttet til det nye estimatet, 10-15\%, gjør det imidlertid ikke mulig å konstatere en forskjell. Ser man på estimatene for tverrsnittstudier (8-11\%) og observasjonsstudier (9-12 \%) hver for seg, er det tilsynelatende ingen forskjell (2).

Fremfor å anerkjenne denne usikkerheten, fokuserer Bramness og Bretteville-Jensen på at andelen avhengige er enda høyere - omkring $18 \%$ - blant dem som bruker cannabis ukentlig eller oftere, og hele 33 \% blant dem som opprettholder slikt bruk over lengre tid. Bramness og Bretteville-Jensen anser disse som mer representative, da de som kun bruker noen få ganger og slutter, neppe kan sies å «bruke». Det er uklart om Bramness og Bretteville-Jensen også mener at alle som drikker alkohol sjeldnere enn hver uke, er å anse som avholdsfolk.

At avhengighet ses oftere hos dem som ruser seg hyppig, er imidlertid neppe stort mer informativt enn at det ses sjeldnere blant dem som ruser seg noen få ganger og slutter. Andelen alkoholavhengige vil også være stor blant dem som frivillig har drukket seg beruset 14 av de siste 14 dagene, men dét betyr ikke at samme andel av et tilfeldig utvalg forsøkspersoner ville bli alkoholavhengige etter to ukers jevnt alkoholkonsum.

De som velger å ruse seg hyppig, vil tross alt kunne ha genetiske trekk, livserfaringer eller andre sårbarheter som gjør dem mer tilbøyelige til både hyppig rusmiddelbruk og avhengighet. Bramness og Bretteville-Jensen ignorerer slike seleksjonseffekter og vil tilsynelatende ha oss til å tro at den høyere forekomsten av avhengighet ved hyppigere bruk forteller oss noe om den «sanne» avhengighetsrisikoen til cannabis. Dette er i så fall en feilslutning.

Den britiske journalisten Ian Betteridge har spøkefullt uttalt at alle overskrifter som slutter med et spørsmålstegn, kan besvares med et «nei». Bramness' og Bretteville-Jensens undring kan neppe avvises så kontant, da det trolig ennå er farer ved cannabis som er blitt undervurdert eller oversett. Det er imidlertid lite hittil som tyder på at avhengighetspotensialet er vesentlig annerledes enn tidligere antatt. 
LITTERATUR:

1. Bramness JG, Bretteville-Jensen AL. Cannabis - farligere enn vi trodde? Tidsskr Nor Legeforen 2020; 140. doi: 10.4045/tidsskr.20.0801. [PubMed][CrossRef]

2. Leung J, Chan GCK, Hides L et al. What is the prevalence and risk of cannabis use disorders among people who use cannabis? a systematic review and meta-analysis. Addict Behav 2020; 109: 106479.

[PubMed][CrossRef]

Publisert: 1. februar 2021. Tidsskr Nor Legeforen. DOI: 10.4045/tidsskr.21.0018

(C) Tidsskrift for Den norske legeforening 2020. Lastet ned fra tidsskriftet.no 